\title{
PERTUMBUHAN DAN HASIL RUMPUT GAJAH KATE (Pennisetum purpureum cv. Mott) YANG DIPUPUK DENGAN PUPUK CAIR LIMBAH BUAH NAGA DENGAN DOSIS BERBEDA
}

\author{
D. E. Dwipa Prasadana, N. M. Witariadi, dan I K. Mangku Budiasa \\ Program Studi Sarjana Peternakan, Fakultas Peternakan, Universitas Udayana, Bali \\ e-mail: dwipaprasadana@student.unud.ac.id
}

\begin{abstract}
ABSTRAK
Penelitian yang bertujuan untuk mengetahui pertumbuhan dan hasil rumput gajah kate (Pennisetum purpureum cv. Mott) yang dipupuk dengan pupuk cair limbah buah naga dengan dosis berbeda. Penelitian dilakukan di Rumah Kaca, Stasiun Penelitian Sesetan, Fakultas Peternakan, Universitas Udayana. Penelitian berlangsung selama 8 minggu, menggunakan rancangan acak lengkap (RAL) dengan enam level dosis dan lima ulangan sehingga terdapat 30 unit percobaan. Perlakuan terdiri atas dosis pupuk cair limbah buah naga yang terdiri atas: o l ha', $2.5001 \mathrm{ha}^{-1}$, 5.000 $1 \mathrm{ha}^{-1}, 7.5001 \mathrm{ha}^{-1}$, $10.0001 \mathrm{ha}^{-1}$, dan $12.500 \mathrm{l} \mathrm{ha}$. Variabel yang diamati yaitu variabel pertumbuhan, variabel hasil dan variabel karakteristik tumbuh. Hasil penelitian menunjukkan bahwa pupuk cair limbah buah naga pada dosis $7.5001 \mathrm{ha}^{-1}$ dapat meningkatkan jumlah daun, sedangkan pada tinggi tanaman dan jumlah anakan menunjukkan hasil yang sama. Pemberian pupuk cair limbah buah naga juga meningkatkan hasil berat kering daun, berat kering batang, dan berat kering total hijauan, namun pada berat kering akar menunjukkan hasil sama. Karakteristik tumbuh tanaman memberikan hasil sama pada variabel nisbah berat kering daun dengan berat kering batang, nisbah berat kering total hijauan dengan berat kering akar, dan luas daun per pot. Dapat disimpulkan bahwa rumput gajah kate (Pennisetum purpureum cv. Mott) yang dipupuk dengan pupuk cair limbah buah naga dapat meningkatkan pertumbuhan dan hasil rumput dan dosis 7.500 1 $\mathrm{ha}^{-1}$ memberikan pertumbuhan dan hasil rumput gajah kate (Pennisetum purpureum cv. Mott) paling baik.
\end{abstract}

Kata kunci: hasil, Pennisetum purpureum cv. Mott, pertumbuhan, pupuk cair limbah buah naga GROWTH AND YIELD OF DWARF ELEPHANT GRASS (Pennisetum purpureum cv. Mott)
FERTILEZED WITH DRAGON FRUIT WASTE LIQUID FERTILIZER WITH DIFFERENT DOSAGE

\begin{abstract}
This study aimed to determine the growth and yield of dwarf elephant grass (Pennisetum purpureum cv. Mott) fertilized with dragon fruit waste liquid fertilizer at different dosage. The research were conducted in the Greenhouse of the Sesetan Research Station, Faculty of Animal Husbandry, Udayana University. The research conducted for 8 weeks, using a completely randomized design (CRD) with six levels and five replications in order to obtain 30 experimental units. Six levels of dragon fruit waste liquid fertilizer was given in this research, which

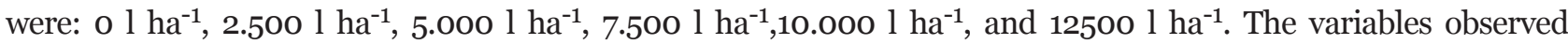
were growth, yield, and growing characteristics variables. The results showed that the application of dragon fruit waste liquid fertilizer increased the number of leaves, while the variables of plant height and number of tillers showed not significant. The application of dragon fruit waste liquid fertilizer increased the yield of leaf dry weight, stem dry weight, and total dry weight forage, but root dry weight showed not significant. Growth characteristics showed not significant on ratio of leaf dry weight to stem dry weight, ratio of total dry weight to root dry weight, and leaf area per pot. It can be concluded that dwarf elephant grass (Pennisetum purpureum cv. Mott) fertilized with dragon fruit waste liquid fertilizer could increase growth and yield at a dosage of 7.500 $\mathrm{ha}^{-1}$ the potential to increase the production and yield of dwarf elephant grass (Pennisetum purpureum cv. Mott).
\end{abstract}

Keywords: yield, Pennisetum purpureum cv. Mott, growth, dragon fruit waste liquid fertilizer

\section{PENDAHULUAN}

Hijauan merupakan pakan utama bagi ternak ruminansia dalam menentukan produktivitas ternak dan penampilan ternak. Hijauan memiliki peranan penting bagi ternak ruminansia dan sebagai sumber gizi yang terdiri dari rumput, legum, dan daun pohon. Menurut Susetyo (1980), hijauan mempunyai peranan penting bagi ternak ruminansia dan merupakan pakan utama sebagai sumber gizi yaitu protein, energi, vitamin, dan 
mineral. Ketersediaan hijuan tidak stabil naik turun tergantung musim, sehingga menjadi kendala dalam pengembangan usaha peternakan. Pakan bagi ternak ruminansia tergantung dari penyediaan hijauan dengan jumlah cukup, berkualitas tinggi, dan berkesinambungan sepanjang tahun. Jenis hijauan unggul yang sering digunakan sebagai pakan oleh petani ternak salah satunya yaitu, rumput Pennisetum purpureum cv. Mott karena ketersediaan di Indonesia yang cukup banyak.

Rumput Pennisetum purpureum cv. Mott banyak ditemukan di Indonesia, karena kondisi iklim tropis dan tekstur tanah yang ada di Indonesia sangat cocok untuk pertumbuhannya. Rumput ini merupakan jenis rumput unggul dan dapat tumbuh di berbagai jenis tanah, sehingga sangat mudah untuk dibudidayakan. Rumput ini diberikan oleh peternak untuk menunjang pertumbuhan dan produktivitas ternaknya karena kandungan zat gizi cukup tinggi serta memiliki palatabilitas yang tinggi bagi ternak ruminansia. Keunggulan lain adalah produksi hijauan tinggi, kandungan protein 10-15\% dan kandungan serat kasar yang rendah (Urribari et al., 2005). Rumput Pennisetum purpureum cv. Mott memiliki kandungan karbohidrat struktural lebih rendah, sehingga memiliki kecernaan yang tinggi. Rumput ini mudah menua karena pertumbuhannya yang cepat, sehingga kandungan nutrisi di dalamnya mudah menurun dan berakibat pada penyerapan unsur hara dalam tanah yang cepat. Peningkatan produktivitas tanaman dapat dilakukan dengan cara pemberian zat hara melalui pemupukan. Beberapa jenis pupuk yang digunakan untuk memenuhi unsur hara dalam meningkatkan produktivitas tanaman dengan pemberian pupuk organik dalam bentuk padat atau bentuk cair.

Pemupukan adalah metode pemberian pupuk ke dalam tanah atau bagian tanaman lainnya dalam bentuk padat atau cair. Pupuk cair lebih mudah dimanfaatkan oleh tanaman karena unsur-unsur di dalamnya sudah terurai sehingga manfaatnya lebih cepat direspon oleh tanaman. Pupuk organik dapat terbuat dari bahan baku berupa kompos, limbah alam, hormon tumbuhan, dan limbah buah yang diproses secara alamiah. Pupuk cair organik selain dapat memperbaiki sifat fisik, kimia, dan biologi tanah, membantu meningkatkan produksi tanaman, meningkatkan kualitas produk tanaman, mengurangi penggunaan pupuk anorganik dan sebagai alternatif pengganti pupuk kandang (Indrakusuma, 2000). Data Pertanian, Perkebunan dan Peternakan Kabupaten Banyuwangi menunjukkan produktivitas buah naga terus meningkat dari tahun ke tahun hingga puncak tertinggi pada tahun 2018 sebesar $33.402 \mathrm{~kg} /$ ha (Dinas Pertanian, dan Pangan Kabupaten Banyuwangi, 2019).

Meningkatnya hasil saat panen raya berujung pada harga buah naga yang anjlok sehingga petani buah naga tidak mendapatkan untung, bahkan banyak buah naga yang dibuang begitu saja ke sungai karena sebagai bentuk protes kemarahan petani akibat harga yang murah. Selain itu limbah buah naga seperti kulit buah dan daging buah yang busuk sering kali hanya dibuang di areal pasar buah dan tidak dimanfaatkan dengan baik, akibatnya menimbulkan bau busuk dan membuat areal pasar menjadi kotor. Limbah buah naga yang sudah tidak dikonsumsi dapat diolah dan dimanfaatkan sebagai pupuk organik cair sebagai salah satu cara untuk memulihkan unsur hara tanah dan mengurangi penggunaan pupuk kimia.

Ningsih (2017) menyatakan bahwa pemberian pupuk organik cair limbah kulit buah naga dan jerami padi dosis $13 \mathrm{ml} /$ polybag, memiliki inhibisi antioksidan tertinggi pada tanaman kangkung darat yaitu sebesar 92,2\%. Hasil analisis menunjukan bahwa unsur nitrogen $(\mathrm{N})$ pada pupuk cair organik campuran kulit buah nanas dan kulit buah naga berada pada kisaran nilai yang masuk dalam standar mutu yaitu $1,57 \%$ pada penyimpanan pekan ke-2 dan pada penyimpanan pekan ke-6 nilai $\mathrm{N}$ meningkat menjadi $5,11 \%$, sedangkan pada pupuk organik cair campuran lain tanpa limbah kulit buah naga (kulit nanas dan kulit jeruk) kandungan nitrogennya menurun yaitu pada pekan ke-2 sebesar 5,21 \% hingga pekan ke-6 menjadi 0,78\% (Kustiawan et al., 2017).

Hasil penelitian Adijaya dan Yasa (2007) tentang pemanfaatan urin sapi yang dilakukan pada rumput raja menunjukan bahwa urin sapi dosis 7500 l/ha, mampu meningkatkan biomassa rumput raja pada panen pertama sebesar 90,18\%, dibandingkan tanpa pemupukan. Hasil penelitian Adijaya dan Sugiarta (2013) pemberian dosis pupuk organik bio urin sapi dosis $7500 \mathrm{l} /$ ha pada tenaman cabai kecil menunjukan produksi dan pertumbuhan yang tertinggi.

Berdasarkan uraian tersebut dilakukan penelitian tentang pertumbuhan dan hasil rumput gajah kate (Pennisetum purpureum cv. Mott) yang diberi pupuk cair limbah buah naga dengan dosis berbeda.

\section{MATERI DAN METODE}

Penelitian dilaksanakan di Rumah Kaca, Stasiun Penelitian Sesetan, Fakultas Peternakan, Universitas Udayana. Bibit yang digunakan adalah bibit rumput gajah kate (Pennisetum purpureum cv. Mott) diperoleh dari Rumah Kaca, Stasiun Penelitian Sesetan, Fakultas Peternakan, Universitas Udayana. Bibit yang digunakan berupa stek batang sepanjang tiga buku sekitar $15 \mathrm{~cm}$. Tanah yang digunakan dalam penelitian ini berasal dari Stasiun Penelitian Fakultas Peternakan Universitas Udayana di Desa Pengotan, Kabupaten Bangli. yang memiliki tekstur pasir berlempung dengan kandungan $\mathrm{C}$ organik 1,22\% (rendah), $\mathrm{N}$ total o,13\% (rendah), P tersedia 45,43 ppm (sangat tinggi), 
kadar air kering udara (KU) 4,07\% dan kapasitas lapang (KL) 30,52\%. Tanah yang akan dipakai terlebih dahulu dikering udarakan, kemudian ditumbuk halus, selanjutnya diayak dengan tujuan agar ukuran partikel tanah merata. Tanah ditimbang dan dimasukkan ke dalam pot yang masing-masing diisi sebanyak 4 $\mathrm{kg}$ tanah kering udara. Tanah dalam pot kemudian disiram dengan air sampai kapasitas lapang.

Percobaan menggunakan pot pot berbahan dasar plastik yang berdiameter $26 \mathrm{~cm}$ dan tinggi $19 \mathrm{~cm}$ sebanyak 30 unit percobaan. Pupuk yang digunakan dalam penelitian adalah pupuk cair limbah buah naga yang dibuat dari limbah buah naga yang berasal dari Banyuwaangi dan analisis dilakukan di Laboratorium Ilmu Tanah, Fakultas Pertanian Universitas Udayana, Denpasar, Bali, Tahun 2020. Pupuk cair limbah buah naga mengandung unsur C-organik 2,73\%, $\mathrm{N}$ o,o6\%, P 167,84\%, K 1157,51\%, pH 4.3.

Rancangan percobaan yang digunakan dalam penelitian ini yaitu rancangan acak lengkap (RAL). Perlakuan yang diberikan adalah dosis pupuk kascing yang terdiri atas : Do: 0 , D1 1 ha $^{-1}: 2.500,1$ ha $^{-1}$ D2: 5.000 , 1 ha $^{-1}$ D3: 7.500 1 ha $^{-1}$, D4: 10.0001 ha $^{-1}$ dan D5: 12.5001 ha $^{-1}$. Setiap perlakuan diulang sebanyak lima kali sehingga terdapat 30 pot percobaan.

Variabel yang diamati dalam penelitian ini: vriabel pertumbuhan: tinggi tanaman, jumlah daun, jumlah anakan; variabel produksi: berat kering daun, berat kering batang, berat kering akar, berat kering total hijauan; variabel karakteristik tumbuh: nisbah berat kering daun dengan berat kering batang, nisbah berat kering total hijauan dengan berat kering akar, dan luas daun per pot $\left(\mathrm{cm}^{2}\right)$.

\section{HASIL DAN PEMBAHASAN}

Hasil penelitian menunjukkan bahwa pertumbuhan rumput gajah kate (Pennisetum purpureum cv. Mott) yang diberi pupuk cair limbah buah naga pada variabel jumlah daun memberikan hasil berbeda nyata $(\mathrm{P}<0,05)$, tetapi pada variabel tinggi tanaman dan jumlah anakan memberikan hasil berbeda tidak nyata $(\mathrm{P}>0,05)$ (Tabel 1). Hasil rumput gajah kate (Pennisetum purpureum cv. Mott) yang diberi pupuk cair limbah buah naga secara nyata $(\mathrm{P}<0,05)$ meningkatkan berat kering daun, berat kering batang, dan berat kering total hijauan tetapi memberikan hasil berbeda tidak nyata $(\mathrm{P}>0,05)$ pada berat kering akar (Tabel 2). Karakteristik tumbuh rumput gajah kate (Pennisetum purpureum cv. Mott) yang diberi pupuk cair limbah buah naga menunjukkan hasil berbeda tidak nyata $(\mathrm{P}>0,05)$ pada semua variabel (Tabel 3$)$.

Pertumbuhan rumput gajah kate (Pennisetum purpureum cv. Mott) yang dipupuk dengan pupuk cair limbah buah naga pada variabel tinggi tanaman dan jumlah anakan memberikan hasil berbeda tidak nyata. Rendahnya pertumbuhan pada variabel tinggi tanaman dan jumlah anakan menunjukkan kurangnya kandungan hara yang tersedia dalam tanah sehingga menghambat pertumbuhan tanaman. Hal ini disebabkan kandungan $\mathrm{N}$ yang sangat rendah yaitu 0,06 \% pada pupuk cair limbah buah naga serta kandungan nitrogen tanah sebesar 0,13\% yang tergolong rendah, sehingga tidak mampu mendukung pertumbuhan tanaman pada variabel tinggi tanaman dan menambah jumlah anakan.

Menurut Soepardi (1983) bahwa peranan utama nitrogen bagi tanaman adalah untuk merangsang pertumbuhan tanaman secara keseluruhan. Lebih lanjut Setyamidjaja (1986) menyatakan bahwa pertambahan tinggi tanaman sangat erat hubungannya dengan ketersediaan unsur hara makro yaitu nitrogen $(\mathrm{N})$. Kadungan $\mathrm{N}$ pupuk cair limbah buah naga yang sangat rendah menyebabkan pertumbuhan akar kurang baik sehingga belum mendukung pertumbuhan jumlah anakan. Sesuai dengan pendapat Rukman (1995) bahwa tanaman yang kekurangan $\mathrm{N}$ menyebabkan tanaman tumbuh kerdil dan memiliki sistem perakaran yang terbatas sehingga jumlah penyerapan hara pada tanaman sedikit. Lebih lanjut Buckman dan Brady (1984) menyatakan bahwa, tanaman yang mengalami peningkatan jumlah tunas mempunyai pertumbuhan sistem perakaran yang baik sehingga pembentukan anakan lebih cepat. Anakan yang tumbuh dari satu tanaman berasal dari pertumbuhan rhizoma-rhizoma yang ada didalam tanah melalui sistem perakaran yang baik (Harjadi, 1984).

Jumlah daun rumput gajah kate (Pennisetum purpureum cv. Mott) semakin meningkat dengan pemberian pupuk cair limbah buah naga dan tertinggi pada dosis $7.500 \mathrm{l} \mathrm{ha}^{-1}$ (Tabel 1). Hal ini karena kandungan unsur hara nitrogen yang lebih mempengaruhi pertumbuhan vegetatif tanaman seperti pertumbuhan daun. Hakim et al. (1986) menyatakan bahwa unsur $\mathrm{N}$ berfungsi dalam pembentukan sel-sel klorofil dimana klorofil berguna dalam proses fotosintesis, sehingga dibentuk energi yang diperlukan sel untuk aktivitas pembelahan, pembesaran dan pemanjangan. Pertumbuhan daun yang banyak akan membantu mempercepat proses fotosintesis dan terjadi peningkatan klorofil daun sebagai bahan penyusun protein dan lemak yang hasilnya ditranslokasikan ke bagian lain dari tanaman dan digunakan untuk pertumbuhan vegetatif dan generatif (Djoehana, 1986). Semakin banyak dan semakin luas daun maka semakin baik proses fotosintesis, sehingga pertumbuhan semakin meningkat.

Berat kering daun, berat kering batang, dan berat kering total hijauan rumput gajah kate (Pennisetum purpureum cv. Mott) semakin meningkat dengan pemberian pupuk cair limbah buah naga. Kandung- 
Tabel 1. Pertumbuhan Rumput Gajah Kate (Pennisetum purpureum cv. Mott) yang Diberi Pupuk Cair Limbah Buah Naga dengan Dosis Berbeda

\begin{tabular}{|c|c|c|c|c|c|c|c|}
\hline \multirow{2}{*}{ Variabel } & \multicolumn{6}{|c|}{ Perlakuan $^{1)}$} & \multirow{2}{*}{$\mathrm{SEM}^{2)}$} \\
\hline & Do & D1 & D2 & D3 & $\mathrm{D} 4$ & $\mathrm{D}_{5}$ & \\
\hline Tinggi tanaman (cm) & $21,00^{\mathrm{a}}$ & $21, \mathrm{OO}^{\mathrm{a}}$ & $21,20^{\mathrm{a}}$ & $21,20^{\mathrm{a}}$ & $21,40^{\mathrm{a}}$ & $20,20^{\mathrm{a}}$ & 1,00 \\
\hline Jumlah daun (helai) & $20,40^{\mathrm{b} 3)}$ & $23, \mathrm{Oo}^{\mathrm{ab}}$ & $23, \mathrm{Oo}^{\mathrm{ab}}$ & $33,40^{\mathrm{a}}$ & $27,80^{\mathrm{a}}$ & $31,20^{\mathrm{a}}$ & 2,75 \\
\hline Jumlah anakan (anakan) & $2,60^{\mathrm{a}}$ & $2,80^{\mathrm{a}}$ & $2,80^{\mathrm{a}}$ & $3,80^{\mathrm{a}}$ & $3,60^{\mathrm{a}}$ & $4,00^{\mathrm{a}}$ & 0,45 \\
\hline
\end{tabular}

Keterangan:

1) Do = o l ha-1, D1 $=2.5001$ ha-1, D2 $=5.0001$ ha-1, D3 =7.50o 1 ha-1, D4 $=10.0001$ ha-1, D5=12.50o 1 ha-1

2) $\mathrm{SEM}=$ Standard Error of theTreatment Means

3) Nilai dengan huruf berbeda pada baris yang sama menunjukkan berbeda nyata $(\mathrm{P}<\mathrm{O}, 05)$

an C-organik pupuk cair limbah buah naga yang tergolong sedang yaitu $2,730 \%$, kandungan $\mathrm{K}$ tersedia dalam pupuk cair 1157,51 ppm, dan kandungan unsur P tersedia dalam pupuk cair 167,84 ppm dan tanah 45,43 ppm yang tinggi mampu meningkatkan kesuburan tanah dan menyediakan unsur hara pada tanaman. Tufaila et al. (2014) menyatakan bahwa dengan memberikan bahan organik atau pupuk organik yang C-organiknya tinggi maka secara tidak langsung telah menyumbangkan C-organik tanah, sehingga C-organik tanah juga meningkat dan dapat memperbaiki struktur tanah. Lebih lanjut Bot et al. (2005) menyatakan bahwa bahan organik dapat memperbaiki struktur tanah dan berfungsi menyerap dan menahan unsur hara dalam bentuk tersedia bagi tanaman. Unsur P sangat penting untuk mendukung peningkatan pertumbuhan dan kualitas hasil. Unsur P merupakan sumber energi untuk proses fototsintesis, respirasi dan penyimpanan energi untuk mengikat unsur hara dalam tanah. Menurut Havlin et al. (1999), fosfor diperlukan oleh tanaman sebagai sumber energi untuk proses fototsintesis, respirasi, transfer dan penyimpanan energi dalam proses pertumbuhan dana perkembangan tanaman. Sedangkan unsur K berfungsi sebagai katalisator dalam pembentukan hasil protein, pembelahan sel dan karbohidrat (Hadisuwito 2007). Unsur hara yang tersedia ini digunakan oleh tanaman untuk meningkatkan hasil berat kering hijauan. Semakin tinggi ketersediaan unsur hara maka tanaman mampu menyerap unsur hara untuk pertumbuhan dan perkembangan tanaman (Agusman 2004). Banyaknya jumlah daun membuat hasil fotosintesis lebih besar untuk cadangan makanan yang ditranslokasikan sebagai hasil berat kering tanaman. Hasil fotosintesis ini digunakan oleh tanaman untuk pertumbuhan dan meningkatkan karbohidrat dan protein tanaman sebagai komponen hasil berat kering tanaman. Hal ini di dukung oleh pernyataan Witariadi et al. (2017) bahwa semakin banyak jumlah daun akan meningkatkan berat kering tanaman. Lebih lanjut Witariadi et al. (2019) jumlah daun yang tinggi membantu proses fotosintesis berjalan dengan maksimal serta karbohidrat dan protein yang dihasilkan akan lebih banyak sebagai komponen penyusun berat kering tanaman, dimana semakin meningkat kandungan karbohidrat dan protein dalam tanaman maka berat kering tanaman semakin tinggi. Gardner et al. (1991) menyatakan bahwa semakin tinggi hasil fotosintesis, semakin besar pula penimbunan cadangan makanan yang ditranslokasikan untuk menghasilkan berat kering tanaman.

Nisbah berat kering daun dengan berat kering batang rumput gajah kate (Pennisetum purpureum cv. Mott) belum mampu ditingkatkan dengan diberi pupuk cair limbah buah naga dan cenderung tertinggi pada dosis 7.500 $1 \mathrm{ha}^{-1}$ dengan rataan sebesar 2,28 g (Tabel 3). Menurut Kurniadi (2010) unsur P sangat penting untuk mendukung peningkatan pertumbuhan dan kualitas hasil. Unsur P merupakan sumber energi untuk proses fototsintesis, respirasi, dan penyimpanan energi untuk mengikat unsur hara dalam tanah. Kandungan unsur P sangat dimaksimalkan untuk pertumbuhan vegetatif tanaman seperti jumlah daun dan pertumbuhan batang. Banyaknya jumlah daun mampu meningkatkan hasil fotosintesis untuk protein dan karbohidrat sebagai komponen hasil berat kering tanaman. Unsur $\mathrm{K}$ berfungsi sebagai katalisator dalam pembentukan hasil protein, pembelahan sel dan karbohidrat. Unsur $\mathrm{K}$ dalam pupuk cair limbah buah naga dimaksimalkan dalam pembentukan hasil berat kering tanaman pada variabel berat kering daun dan batang sehingga nisbah berat kering daun dengan berat kering batang menunjukkan hasil yang kurang baik. Nisbah berat kering daun dengan berat kering batang dipengaruhi oleh nilai berat kering daun dan berat kering batang. Bila nilai berat kering daun lebih rendah dari nilai berat kering batang, maka nilai nisbah berat kering daun dengan berat kering batangnya kecil. Nilai ini menunjukkan kualitas hijauan pakan yaitu hijauan dikatakan memiliki kualitas baik apabila nisbahnya memberikan hasil yang tinggi. Pendapat Setyawan et al. (2016) yang menyatakan semakin tinggi porsi daun suatu tanaman dan porsi batang yang lebih kecil maka nisbah berat kering daun dan berat kering batang akan semakin tinggi.

Nisbah berat kering total hijauan dengan berat kering akar rumput gajah kate (Pennisetum purpureum cv. Mott belum mampu ditingkatkan dengan diberi pupuk cair limbah buah naga dan cenderung tertinggi pada dosis $7.5001 \mathrm{ha}^{-1}$ dengan rataan sebesar 
Tabel 2. Hasil Rumput Gajah Kate (Pennisetum purpureum cv. Mott) yang Diberi Pupuk Cair Limbah Buah Naga dengan Dosis Berbeda

\begin{tabular}{|c|c|c|c|c|c|c|c|}
\hline \multirow{2}{*}{ Variabel } & \multicolumn{6}{|c|}{ Perlakuan ${ }^{1)}$} & \multirow{2}{*}{$\mathrm{SEM}^{2)}$} \\
\hline & Do & D1 & D2 & D3 & $\mathrm{D} 4$ & D5 & \\
\hline Berat kering daun (g) & $4,76^{\mathrm{b} 3)}$ & $4,56^{b}$ & $5,04^{\mathrm{ab}}$ & $7,24^{\mathrm{a}}$ & $6,96^{\mathrm{a}}$ & $7,28^{a}$ & 0,64 \\
\hline Berat kering batang (g) & $2,20^{\mathrm{b}}$ & $2,34^{\mathrm{b}}$ & $2,66^{\mathrm{ab}}$ & $3,14^{\mathrm{ab}}$ & $4,14^{\mathrm{a}}$ & $3,96^{\mathrm{a}}$ & 0,34 \\
\hline Berat kering akar (g) & $5,68^{\mathrm{a}}$ & $5,46^{\mathrm{a}}$ & $6,64^{\mathrm{a}}$ & $7,14^{\mathrm{a}}$ & $10,06^{\mathrm{a}}$ & $8,94^{\mathrm{a}}$ & 1,15 \\
\hline Berat kering total hijauan (g) & $6,96^{b}$ & $6,90^{b}$ & $7,70^{\mathrm{ab}}$ & $10,38^{\mathrm{a}}$ & $11,10^{\mathrm{a}}$ & $11,34^{\mathrm{a}}$ & 1,17 \\
\hline
\end{tabular}

Keterangan:

1) Do = o l ha-1, D1 = 2.500 l ha-1, D2 = 5.00o l ha-1, D3 =7.500 1 ha-1, D4 = 10.0001 ha-1, D5= 12.500 1 ha-1

2) $\mathrm{SEM}=$ Standard Error of theTreatment Means

3) Nilai dengan huruf berbeda pada baris yang sama menunjukkan berbeda nyata $(\mathrm{P}<0,05)$

Tabel 3. Karakteristik Rumput Gajah Kate (Pennisetum purpureum cv. Mott) yang Diberi Pupuk Cair Limbah Buah Naga dengan Dosis Berbeda

\begin{tabular}{|c|c|c|c|c|c|c|c|}
\hline \multirow{2}{*}{ Variabel } & \multicolumn{6}{|c|}{ Perlakuan $^{1)}$} & \multirow{2}{*}{$\mathrm{SEM}^{2)}$} \\
\hline & Do & D1 & D2 & D3 & D4 & D5 & \\
\hline Nisbah berat kering daun dengan berat kering batang & $2,19^{\mathrm{a} 3)}$ & $2,02^{\mathrm{a}}$ & $1,89^{\mathrm{a}}$ & $2,27^{\mathrm{a}}$ & $1,72^{\mathrm{a}}$ & $1,94^{\mathrm{a}}$ & 0,20 \\
\hline Nisbah berat kering total hijauan dengan berat kering akar & $1,34^{\mathrm{a}}$ & $1,33^{\mathrm{a}}$ & $1,19^{\mathrm{a}}$ & $2,04^{\mathrm{a}}$ & $1,19^{\mathrm{a}}$ & $1,30^{\mathrm{a}}$ & 0,34 \\
\hline Luas daun per pot $\left(\mathrm{cm}^{2}\right)$ & $1.256,46^{\mathrm{a}}$ & $1.366,77^{\mathrm{a}}$ & $1.217,51^{\mathrm{a}}$ & $1.729,95^{\mathrm{a}}$ & $1.587,60^{\mathrm{a}}$ & $1.747,06^{\mathrm{a}}$ & 226,89 \\
\hline
\end{tabular}

Keterangan:

1) Do = o l ha-1, D1 = 2.500 l ha-1, D2 = 5.00o 1 ha-1, D3 =7.500 l ha-1, D4 = 10.000 l ha-1, D5= 12.500 1 ha- 1

2) SEM $=$ Standard Error of theTreatment Means

3) Nilai dengan huruf yang sama pada baris yang sama menunjukkan berbeda tidak nyata $(\mathrm{P}>, 05)$

2,04 g (Tabel 3). Nisbah berat kering total hijauan dengan berat kering akar dipengaruhi oleh nilai berat kering total hijauan dan berat kering akar. Bila nilai berat kering total hijauan lebih rendah dari nilai berat kering akar, maka nilai nisbah berat kering total hijauan dengan berat kering akarnya kecil.

Luas daun per pot rumput gajah kate (Pennisetum purpureum cv. Mott) yang diberi pupuk cair limbah buah naga tidak mengalami peningkatan dan kecenderungan menunjukan hasil tertinggi pada dosis $12.500 \mathrm{l} \mathrm{ha}^{-1}$ dengan rataan sebesar $1.747,06 \mathrm{~cm}^{2}$ (Tabel 3). Hal ini karena kandungan $\mathrm{N}$ yang rendah di dalam pupuk cair limbah buah naga tidak mampu mencukupi kebutuhan tanaman, sehingga unsur $\mathrm{N}$ yang ada pada pupuk cair limbah buah naga lebih banyak mempengaruhi pertumbuhan vegetatif untuk pertumbuhan jumlah daun. Pendapat ini didukung oleh Rachman dan Murdiyati (1987) yang menyatakan bahwa semakin tinggi dosis $\mathrm{N}$ semakin mempengaruhi panjang dan lebar daun produksi. Lebih lanjut Poerwowidodo (1992) dan Sutedjo (2002) yang menyatakan bahwa nitrogen diperlukan untuk merangsang pertumbuhan vegetatif, memperbesar ukuran daun, dan meningkatkan kandungan klorofil. Peningkatkan klorofil pada daun akan mempercepat proses fotosintesis, semakin meningkat proses fotosintesis maka pertumbuhan dan produksi semakin meningkat. Disamping itu jumlah daun yang tinggi pada dosis yang sama juga mempengaruhi luas daun, semakin besar luas daun maka fotosintesis semakin meningkat, karena energi matahari yang diterima semakin banyak untuk membantu proses pertukaran karbohidrat, $\mathrm{CO}_{2}$ dan $\mathrm{H}_{2} \mathrm{O}$ sehingga produksi yang dihasilkan semakin meningkat (Candraasih et al., 2014).

\section{SIMPULAN}

Berdasarkan hasil penelitian ini dapat disimpulkan bahwa pemberian pupuk cair limbah buah naga dapat meningkatkan pertumbuhan dan hasil rumput gajah kate (Pennisetum purpureum cv. Mott). Rumput gajah kate (Pennisetum purpureum cv. Mott) yang diberi pupuk cair limbah buah naga pada dosis 7.500 1 ha $^{-1}$ memberikan pertumbuhan dan hasil yang paling baik.

\section{DAFTAR PUSTAKA}

Adijaya, I N. dan I M. R.Yasa. 2007. Pemanfaatan Bio Urin dalam Produksi Hijauan Pakan Ternak (Rumput Raja). Prosiding Seminar Nasional Dukungan Inovasi Teknologi dan Kelembagaan dalam Mewujudkan Agribisnis Industrial Pedesaan. Mataram pada tanggal 22-23 Juli 2007. Balai Besar Pengkajian dan Pengembangan Teknologi Pertanian. Jakarta. Hal. 155- 157.

Adijaya, I. N. dan Sugiarta P. 2013. Meningkatkan Produktivitas Cabai Kecil Dengan Aplikasi Bio Urin Sapi. Seminar nasional inovasi teknologi pertanian.

Agusman, A. R. 2004. Pengaruh Pemberian Pupuk Kompos dan N P K. Terhadap Serapan K dan Hasil Tanaman Jagung Pada Tanah Entisol. Skripsi S1 Fakultas Pertanian UNS. Surakarta.

Bot, A. and J. Benites, 2005. The importance of soil organic matter Key to droughtresistant soil and sustained food and production. FAO Soils Bulletin 8o Rome.Djoehana, S. 1986. Pupuk dan Pemupukan, Cetakan Pertama. CV. Simplex, 
Jakarta.

Buckman dan N.C. Bardy. (1984). Ilmu Tanah. Bhatara Karya Aksara. Jakarta.

Candraasih Kusumawati, N. N., A. A. A. S. Trisnadewi dan N. W. Siti,. (2014). Pertumbuhan dan hasil stylosanthes guyanensis cv ciat 184 pada tanah entisol dan inceptisol yang diberikan pupuk organik kascing. Majalah Ilmiah Peternakan Volume 17 Nomor 2 Tahun 2014. Fakultas Peternakan Universitas Udayana, Denpasar. https://ojs.unud.ac.id/index.php/mip/article/ view/10917

Dinas Pertanian dan Pangan Kabupaten Banyuwangi. 2019. Data Pertanian, Perkebunan dan Peternakan. Profil Kabupaten Banyuwangi.

Djoehana, SE. Ed. 1986. Pupuk dan Pemupukan, Cetakan Pertama. CV Simplek, Jakarta.

Gardner, F. P. and B. Pearce. 1991. Fisiologi Tanaman Budidaya (terjemahan dari Physiology of Crop Plants oleh Herawati Susilo). Universitas Indonesia. Jakarta.

Hadisuwito, S. 2007. Membuat Pupuk Kompos Cair. Penerbit Agromedia Pustaka. Jakarta.

Hakim, N. Nyakpa, Lubis, Nugroho, Saul, A. Dida, G. B. Hong dan Balley. 1986. Dasar-dasar Ilmu Tanah. Universitas Lampung, Bandar Lampung.

Harjadi, S.S. (1984). Pola PertumbuhanTanaman. Penerbit PT.Gramedia. Jakarta.

Havlin, J. L., J.D. Beaton, S.M. Tisdale, and W.L. Nelson. 1999. Soil Fertility and Fertilizers. An introduction to Nutrient Management. Prentice Hall, Upper Saddle River, New Jersey. P.154-194.

Indrakusuma. 2000. Pupuk Organik Cair Supra Alam Lestari. PT Surya Pratama Alam. Yogyakarta.

Kurniadi, H. 2010. P Jaringan dan P Tersedia Tanah Serta Hasil Tanaman Padi Pada Berbagai Macam Pemupukan di Lahan Sawah Palur Sukoharjo. Universitas Sebelas Maret, Surakarta.

Kustiawan, W., Nurhiftiani, I. Sembiring, K. H. M. dan Ediyono, R. P. 2017. Pemanfaatan Limbah Kulit Buah-buahan Sebagai Bahan Baku Pembuatan Pupuk Organik Cair. Laboratorium Silvikultur Fakultas Kehutanan Universitas Mulawarman. Samarinda.

Ningsih, T. A. P. 2017 Pengaruh Pemberian Pupuk Organik Cair Limbah Kulit Buah Naga dan Jerami Padi Terhadap Kandungan Antioksidan Dan Pertumbuhan Tanaman Kangkung Darat (Ipomoea reptans, Poir.) Surakarta.
Poerwawidodo. 1992. Telaah Kesuburan Tanah. Penerbit Angkasa. Bandung.

Ranchman, A. dan A,S. Murdiyanti. 1987. Pengaruh Dosis Pupuk N dan P terhadap Produksi dan Mutu Tembakau Madura pada Tanah Aluvial. Penelitian Tanaman Tembakau dan Serat Vol. 2 No. 1-2, 1987

Rukman, R. (1995). Usaha Tani Jagung. Kanisius. Yogyakarta.

Setyamidjaja, D. M. E. 1986. Pupuk dan Pemupukan. Penerbit CV. Simplex. Jakarta.

Setyawan, Y., N. G. K. Roni dan N. N. C. Kusumawati. 2016. Pertumbuhan dan Produksi Tanaman Indigofera zollingeriana Pada Berbagai Dosis Pupuk Fosfat. Peternakan Tropika Vol. 4 No. 3 Th. 2016: 656 - 672. Fakultas Peternakan Universitas Udayana, Denpasar. https://ojs. unud.ac.id/index.php/tropika/issue/view/2279 Soepardi, G. 1983. Sifat dan Ciri Tanah. Fakultas Pertanian Institut Pertanian Bogor. Bogor

Susetyo, B. 1980. Padang Penggembalaan. Departemen Ilmu Makanan Ternak Fakultas Peternakan IPB. Bogor.

Sutedjo, R. 2002. Pertanian Organik Menuju Pertanian Alternatif dan Berkelanjutan. Penerbit Kasinius. Yogyakarta.

Tufaila, M dan S. Alam. 2014. Karakteristik tanah dan evaluasi lahan untuk pengembangan tanaman padi sawah di kecamatan oheo kabupaten konawe utara. Jurnal ilmiah Volume 24 Nomor : 02 Mei 2014. Kendari

Urribarri L, Ferrer A, Colina A. 2005. Leaf protein from ammonia- treated dwarf elephant grass (Pennisetum purpureum cv. Mott). Appl Biochem Biotechnol. 121-124:721-730.

Witariadi, N. M., I K. M. Budiasa., N. N. C. Kusumawati., I. G. Suranjaya dan N.G. K Roni. 2017. Pengaruh jarak tanam dan dosis biourin terhadap pertumbuhan dan hasil rumput Panicum maximum pada pemotongan ketiga. Pastura Volume 17 Nomor 2 Tahun 2017. Fakultas Peternakan Universitas Udayana, Denpasar. https://ojs.unud.ac.id/index.php/pastura/ article/view/45431.

Witariadi, N. M. dan N. N. C. Kusumawati. 2019. Produktivitas kacang pinto (Arachis pintoi) yang dipupuk dengan jenis dan dosis pupuk organik berbeda. Majalah Ilmiah Peternakan Volume 22 Nomor 2 Tahun 2019. Fakultas Peternakan Universitas Udayana, Denpasar. https://ojs. unud.ac.id/index.php/mip/article/view/5479o 